\title{
MEMAKSIMALKAN METODE PEMBELAJARAN SECARA DARING DITENGAH WABAH COVID-19
}

\author{
Taufiq Rahman Ilyas*, Alvin Nur Chahya Rahman, Riska Aisyah Putri, Rofiatul \\ Maghfiroh, Riski Nanda Aldino, Rulita Risfatma Putri, Roudhotul Angelika Wibowo, \\ Lina Kusumawati, Chillatus Syarifah, Devi Permana, Sukma Faradiba \\ Fakultas Ilmu Administrasi, Universitas Islam Malang \\ *korespondensi email: taufiq@unisma.ac.id
}

\begin{abstract}
ABSTRAK
Pendidikan sangatlah penting untuk menunjang generasi bangsa yang berkualitas dan unggul. Oleh sebab itu pendidikan harus tetap dilaksanakan walaupun dalam keadaan yang bagaimanapun, dalam hal ini pemerintah mewajibkan para anak bangsa untuk menempuh pendidikan selama 12 tahun. Dengan adanya virus Covid 19 ini sistem pendidikan yang biasa dilakukan secara normal menjadi terganggu atau terpaksa diberhentikan guna memutus tali persebaran Covid 19. Melihat hal tersebut semakin menurunya kualitas pendidikan di Indonesia maka dari itu metode pendidikan harus tetap dilakukan walupun tidak dengan keadaan normal atau tatap muka. Maka dari itu menteri pendidikan memberikan penyelesaian atas masalah tersebut dengan memunculkan metode baru yang biasa disebut dengan "metode daring". Metode daring adalah sebuah metode pembelajaran yang dilakukan secara online dengan menggunakan aplikasi seperti goolel meet, zoom dst. Dengan adanya metode daring tersebut maka proses pemebelajaran tetap terlaksanan tanpa adanya kereaguan tertular virus Covid 19 . Akan tetapi banyak masyarakat yang tidak mampu dalam melaksanakan metode tersebut dikarenakan biaya kuota yang besar atau tidak memiliki media elektronik, sehingga bisa disimpulkan bahwa metode daring tersebut belum sepenuhnya berjalan secara maksimal pada masyarakat desa.
\end{abstract}

Kata Kunci: metode; pembelajaran daring; pandemi covid 19

\section{PENDAHULUAN}

Wabah corona virus disease 2019 (Covid-19) yang telah melanda 215 negara di dunia (Safi et al., 2021), memberikan tantangan tersendiri bagi lembaga pendidikan, khususnya Pendidikan Pada Anak Usia Dini (PAUD, TK, RA) (Haryanti et al., 2020). Untuk melawan Covid-19 Pemerintah telah melarang untuk berkerumun, pembatasan sosial (social distancing) dan menjaga jarak fisik (physical distancing), memakai masker dan selalu cuci tangan (Sadikin \& Hamidah, 2020). Melalui Kementerian Pendidikan dan Kebudayaan Pemerintah telah melarang sekolah-sekolah untuk melaksanakan pembelajaran tatap muka (konvensional) dan memerintahkan untuk menyelenggarakan pembelajaran secara daring (Surat Edaran Kemendikbud Dikti No. 1 tahun 2020). Sekolahsekolah dituntun untuk dapat menyelenggarakan pembelajaran secara daring atau online (Sari et al., 2021).

Untuk mencegah penyebaran Covid-19, WHO memberikan himbauan untuk menghentikan acara-acara yang dapat menyebabkan massa berkerumun (Hamidi, 2020). 
Maka dari itu, pembelajaran tatap muka yang mengumpulkan banyak siswa di dalam kelas ditinjau ulang pelaksanaanya. Pembelajaran harus diselenggarakan dengan skenario yang mampu mencegah berhubungan secara fisik antara guru dengan murid (Basar, 2021). penggunaan teknologi digital dapat memungkinkan siswa dan guru dalam melaksanakan proses pembelajaran walaupun mereka ditempat yang berbeda (Firman \& Rahayu, 2020).

Akan tetapi kondisi perekonomian masyarakat di Desa Poncokusumo tepatnya di Dusun Wates tidak memungkinkan untuk melakukan pembelajaran daring dengan alasan keterbatasan media elektronik. Selain itu banyak para orang tua yang sibuk untuk mencari mata pencaharian demi mencukupi kehidupan keluarganya, sehingga banyak para siswa yang terabaikan kebutuhan pendidikannya, serta semangat mereka untuk mempelajari ilmu pendidikan pun menurun.

Berdasarkan analisis tersebut metode serta upaya guna memaksimalkan pembelajaran sangatlah penting agar anak-anak usia dini tidak merasa bosan maka para ibu guru membantu mereka untuk melasanakan pembelajaran dengan cara home visit yang mana hanya melibatkan 5-7 siswa saja dengan durasi waktu kurang lebih 30 menit, sisanya dilakukan di hari berikutnya. Dengan begitu tidak ada lagi anak-anak yang terabaikan masalah pendidikannya dan mereka kembali semangat dalam pelaksanaan pembelajaran.

Mengingat masih berada dalam masa new normal, dan kondisi pandemi masih berlangsung, maka setiap siswa yang datang untuk belajar diwajibkan untuk berjarak dengan siswa lainnya serta melakukan protokol kesehatan seperti yang dianjurkan oleh pemerintah. Seperti menggunakan masker dan memakai handsainitizer ketika akan melakukan pembelajaran.

\section{METODE}

Adapun metode yang akan dilakukan dalam kegiatan pengabdian masyarakat ini adalah sebagai berikut:

1. Metode studi kasus pada Lembaga Pendidikan PAUD, TK, RA, SD di desa Poncokusumo Dusun Wates.

2. Metode sosialisai dalam membantu pendidikan metode daring dengan cara home visit.

3. Metode Demonstrasi, meliputi pengenalan Langkah-langkah pembelajaran home visit atau belajar bersama.

4. Metode praktik, meliputi pembelajaran daring yang dilaksanakan dengan home visit di salah satu rumah siswa.

5. Metode evaluasi, berupa respon dan partisipasi para anak-anak Desa Poncokusumo Dusun Wates.

Tahap pembelajaran daring dengan cara home visit terbagi dalam beberapa langkah, yaitu sebagai berikut:

1. Tahap Sosialisasi

a. Pengenalan metode pembelajaran daring

Pengenalan metode pembelajaran daring ini dilakukan dengan cara home visit kepada ibu-ibu PKK.

b. Persetujuan atas pembelajaran daring

Persetujuan atas pembelajaran daring dengan cara home visit oleh lembaga pendidikan (PAUD, TK, RA, SD).

2. Tahap Pelaksanaan

a. Menentukan tempat untuk home visit

Untuk menentukantempat pelaksanaan metode daring akan dilakukan oleh siswa sebanyak 5 - 7 siswa. 
b. Mulai melaksanakan pembelajaran daring

Kegiatan pelaksanaan pembelajaran daring ini dilakukan dengan cara home visit.

\section{HASIL DAN PEMBAHASAN}

Program Pengabdian Masyarakat ini dibuat untuk membantu pemeblajaran metode daring dengan cara home visit pada anak-anak di Desa Poncokusumo Dusun Wates, dengan cara melakukan pembelajaran metode terebut menjadikan anak- anak semakin rajin dan semangat dalam melakukan pembelajaran, disisi lain pendidikan mereka menjadi tidak terabaikan. Dalam hal ini pembelajaran di Dusun Wates menjadi maksimal walaupun sedang dalam keadaan pandemi virus covid 19.

\section{Tahap Sosialisasi}

Pada tahap sosialisasi ini tim pelaksana melakukan pengenalan kepada masyarakat Dusun Wates terutama kepada ibu-ibu PKK tentang pembelajaran daring dengan cara home visit serta tentang pentingnya sebuah pendidikan pada masa usia dini.

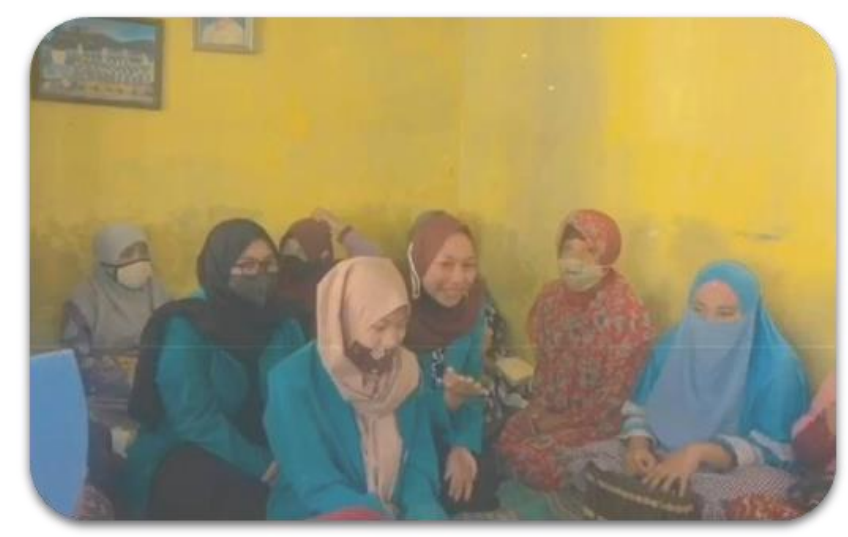

Gambar 1. Pengenalan kepada ibu-ibu PKK

\section{Tahap Pelaksanaan}

Pada tahap pelaksanaan ini tim mulai melakukan pembelajaran daring dengan cara home visit. Yang mana diawali dengan menentukan tempat dimana pembelajaran akan dilaksanakan, disini kami mengambil tempat yang mudah dijangkau oleh siswa serta tidak jauh dari rumah siswa yang lainya. Kemudian kami membagi siswa yang ingin belajar menjadi beberapa kelompok yang mana kelompok tersebut terdiri dari $5-7$ orang siswa dengan durasi kurang lebih 30 menit. Dikarenakan banyaknya anak yang antusias dengan pembelajaran ini maka kami membagi home visit lagi di keesokan harinya.

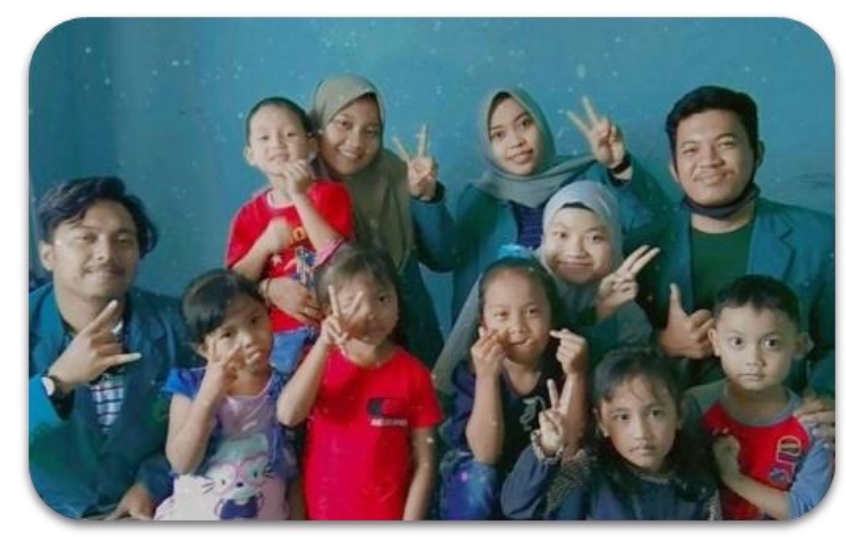

Gambar 2. Kegiatan proses pembelajaran daring 


\section{KESIMPULAN}

Kegiatan Kuliah Kerja Nyata (KKN-PPM) berbasis home visited yang dilaksanakan oleh kelompok 61 Mahasiswa Universitas Islam Malang dengan Tema "Pembelajaran Home Visited Dalam Masa Pandemi Covid-19" mendapatkan sambutan positif dari masyarakat dan siswa-siswi Sekolah Dasar Desa Tanjung.

Program yang dilaksanakan adalah pembelajaran home visited dan menerapkan sistem protokol kesehatan, dengan adanya pembelajaran berbasis homevisited ini sekaligus memberikan jawabpan dari permasalahan yang dihadapi banyak wali murid yang kurang mampu memberi kuota untuk anaknya dan membantu para siswa-siswi memahami lebih jelas terkait pelajaran yang di terima.

\section{UCAPAN TERIMA KASIH}

Ucapan terima kasih disampaikan kepada kepala Desa Tanjung beserta Perangkat Desa dan Kepala Dusun Tanjung yang telah menerima dan membantu mahasiswa peserta KKN-PPM selama 1 bulan dan menjalankan program kerja.Ucapan terima kasih juga disampaikan kepada Panitia KKN-PPM dan Ketua LPPM Universitas Islam Malang yang telah memberikan kesempatan dan memudahkan terlaksananya kegiatan KKN- PPM.

\section{DAFTAR RUJUKAN}

Basar, A. M. (2021). Problematika Pembelajaran Jarak Jauh Pada Masa Pandemi Covid-19. Edunesia: Jurnal Ilmiah Pendidikan, 2(1), 208-218. https://doi.org/10.51276/edu.v2i1.112

Firman, \& Rahayu, S. (2020). Pembelajaran Online di Tengah Pandemi Covid-19. Indonesian Journal of Educational Science (IJES), 2(2), 81-89. https://doi.org/10.31605/ijes.v2i2.659

Hamidi, A. (2020). Workshop Efektivitas Pembelajaran Daring pada Masa Pandemi Covid 19 di Prodi Ikor. Jurnal MAENPO: Jurnal Pendidikan Jasmani Kesehatan Dan Rekreasi, 10(2), 109-118. https://doi.org/10.35194/jm.v10i2.1124

Haryanti, P., Hidayati, A., Rodliyah, I., Nisful Laili, C., \& Saraswati, S. (2020). Sosialisasi Literasi Keuangan Syariah Pada Anak Usia Dini. Jurnal Inovasi Hasil Pengabdian Masyarakat (JIPEMAS), 3(2), 136-145. https://doi.org/10.33474/jipemas.v3i2.6584

Sadikin, A., \& Hamidah, A. (2020). Pembelajaran Daring di Tengah Wabah Covid-19. Biodik: $\begin{array}{llll}\text { Jurnal Ilmiah Pendidikan } & \text { 109-119. }\end{array}$ https://doi.org/10.22437/bio.v6i2.9759

Safi, I., Candra, A. I., Widodo, S. R., Santoso, A., Heryanto, B., Winarti, E., \& Rahmadi, A. N. (2021). Pembuatan masker dan bilik disinfektan sebagai upaya membantu masyarakat terdampak covid-19. Jurnal Inovasi Hasil Pengabdian Masyarakat (JIPEMAS), 4(1), 36-45. https://doi.org/10.33474/jipemas.v4i1.7524

Sari, P. R., Tusyantari, N. B., \& Suswandari, M. (2021). Dampak Pembelajaran Daring bagi Siswa Sekolah Dasar Selama Selama Covid-19. Prima Magistra: Jurnal Ilmiah Kependidikan, 2(1), 9-15. https://doi.org/10.37478/jpm.v2i1.732 